\title{
Determination of Natural Radioactivity in Soil Samples around Gold Mining Area in Khamkeut District, Bolikhamxay Province,Laos Using Gamma Ray Spectrometer with $\mathrm{NaI}(\mathrm{Tl})$ Detector
}

\author{
Somsavath Leuangtakoun ${ }^{1,2}$, Bui Thi Hong ${ }^{1}$, Bui Van Loat ${ }^{1, *}$, Phan Viet Cuong ${ }^{3}$ \\ ${ }^{I}$ Faculty of Physics, VNU University of Science, 334 Nguyen Trai, Hanoi, Vietnam \\ ${ }^{2}$ National University of Laos, P.O.Box: 7322, Dongdo Vientiane, Laos \\ ${ }^{3}$ Institude of Physics, VAST, 1 DaoTan, Hanoi, Vietnam
}

Received 15 May 2018

Revised 25 July 2018; Accepted 26 July 2018

\begin{abstract}
This paper presented the method of determining the radioactivity of ${ }^{40} \mathrm{~K},{ }^{226} \mathrm{Ra}$ and ${ }^{232} \mathrm{Th}$ in soil samples by gamma-ray spectrometerusing $\mathrm{NaI}(\mathrm{Tl})$ scintillation detector. The radioactivity of each isotope is calculated based on the net count rate in the energy window characteristics for the ${ }^{40} \mathrm{~K},{ }^{226} \mathrm{Ra}$ and ${ }^{232} \mathrm{Th}$ radioisotopes respectively. We have determined activity concentrations of the natural radionuclides ${ }^{226} \mathrm{Ra},{ }^{232} \mathrm{Th}$ and ${ }^{40} \mathrm{~K}$ in 15 soil samples collected around gold mines of Khamkeut district, Bolikhamxay Province, Laos. The average activity concentrations of the natural radionuclides ${ }^{226} \mathrm{Ra},{ }^{232} \mathrm{Th}$ and ${ }^{40} \mathrm{~K}$ are $46.58 \pm 7.36,71.19 \pm 5.42$ and $574.62 \pm 25.02 \mathrm{~Bq}^{\mathrm{kg}} \mathrm{kg}^{-1}$, respectively. The average activity concentrations of ${ }^{226} \mathrm{Ra}$ and ${ }^{232} \mathrm{Th}$ in this work are higher than those of Bolikhamxay Province, Laos and the world average values. The estimated average outdoor annual effective dose $(\mathrm{E})$ and radium equivalent actitvity $\left(\mathrm{Ra}_{\mathrm{eq}}\right)$ are $0.10 \pm 0.004 \mathrm{mSv}_{\mathrm{yr}} \mathrm{r}^{-1}$ and $192.64 \pm 16.12 \mathrm{~Bq} \cdot \mathrm{kg}^{-1}$, respectively.
\end{abstract}

Keywords: Gamma-ray-spectroscopy, NaI(Tl) detector, ROI, student's t distribution, Radiological Hazard Assessment.

\section{Introduction}

Measurement of natural environmental radiation is very important and of particular concern to human health. The major sources radiological exposure are natural radionuclides namely ${ }^{238} \mathrm{U}$ and ${ }^{232} \mathrm{Th}$ series and ${ }^{40} \mathrm{~K}$, which occur in the earth' scrust since its origin. Natural radioactivity in environmental is the main source radiation exposure to the human body. The ${ }^{226} \mathrm{Ra}$ subseries

\footnotetext{
*Corresponding author. Tel.: 84-912865869.

Email: Loat.bv58@gmail.com

https//doi.org/ 10.25073/2588-1124/vnumap.4270
} 
contribute about $98 \%$ of the external $\gamma$ dose induced by whole ${ }^{238} \mathrm{U}$ series. Radiological hazard parameters are calculated based on the specific radioactivity of ${ }^{40} \mathrm{~K},{ }^{226} \mathrm{Ra}$ and ${ }^{232} \mathrm{Th}$ in the soil samples [1-3]. The low resolution energy of the $\mathrm{NaI}(\mathrm{Tl})$ detector with full width at half maximum (FWHM) is $70 \mathrm{keV}$ at the $1332 \mathrm{keV}$, there are many overlapping full energy peaks of natural radiation isotopes. Moreover, the radioactivity of environmental sampleswasvery small, so the appearance of full energy peaks were not clear. For the NaI detector, radioactivity is based on detection gamma radiation of $1460.8 \mathrm{keV}$ for ${ }^{40} \mathrm{~K}$, from ${ }^{214} \mathrm{Bi}(1764 \mathrm{keV})$ for ${ }^{226} \mathrm{Ra}$ series and from ${ }^{208} \mathrm{Tl}(2614 \mathrm{keV})$ for series $[4,5]$. The activity of each isotope is determined based on the net count rate (cps) measured in energy region of interest (ROI) for each isotope. The net count rate measured in the $\mathrm{i}-$ th ROIcan be expessed as follows [4]:

$$
n_{i}=\sum_{k} a_{i k} A_{k} \quad i=1,2,3
$$

where $n_{i}$ is the cps measured in the $\mathrm{i}-$ th ROI, $A_{k}$ is the activity concentrion of nuclide $k(k=1,2,3$ for ${ }^{40} \mathrm{~K},{ }^{226} \mathrm{Ra},{ }^{232} \mathrm{Th}$ ), matrix $\mathrm{a}_{\mathrm{ik}}$ is an instrumentresponsedefined as net count rate in $\mathrm{i}$ th ROI for unit activity of the isotope $\mathrm{k}$.

Matrix of instrument response equation reference goes here $\left\|a_{i k}\right\|$ is calculated by the method of MCNP simulations [4]. In this work, matrix of instrument response $\left\|a_{i k}\right\|$ were determined. Activity concentration of ${ }^{40} \mathrm{~K},{ }^{226} \mathrm{Ra},{ }^{232} \mathrm{Th}$ in a soil sample calculated by matrix method. The obtained results have been compared with the laboratories measurements by using a HPGe detector.

\section{Methods and materials}

\subsection{Geological outline}

Table 1. The position of soil samplescollected around the gold mining area in Khamkeut district

\begin{tabular}{llll}
\hline Item & GPS Position & & \\
\cline { 2 - 4 } & Latitude & Longtitude & Elevation $(\mathrm{m})$ \\
\hline K1 & $18^{\circ} 0^{\prime} 34.6104^{\prime \prime}$ & $9^{\circ} 3^{\prime} 16.362^{\prime \prime}$ & 636 \\
K2 & $18^{\circ} 8^{\prime} 30.6096^{\prime \prime}$ & $9^{\circ} 1^{\prime} 13.512^{\prime \prime}$ & 513 \\
K3 & $18^{\circ} 11^{\prime} 2.7636^{\prime \prime}$ & $9^{\circ} 0^{\prime} 40.475^{\prime \prime}$ & 523 \\
K4 & $18^{\circ 1} 1^{\prime} 34.908^{\prime \prime}$ & $9^{\circ} 1^{\prime} 14.76^{\prime \prime}$ & 513 \\
K5 & $18^{\circ} 11^{\prime} 37.5504^{\prime \prime}$ & $8^{\circ} 59^{\prime \prime} 52.987^{\prime \prime}$ & 517 \\
K6 & $18^{\circ} 10^{\prime} 43.5432^{\prime \prime}$ & $9^{\circ} 2^{\prime} 56.468^{\prime \prime}$ & 531 \\
K7 & $18^{\circ} 15^{\prime} 28.7532^{\prime \prime}$ & $9^{\circ} 1^{\prime} 33.6^{\prime \prime}$ & 532 \\
K8 & $18^{\circ} 11^{\prime} 17.2^{\prime \prime}$ & $9^{\circ} 7^{\prime} 29.5^{\prime \prime}$ & 537 \\
K9 & $18^{\circ} 11^{\prime} 39.9696$ & $9^{\circ} 7^{\prime} 36.322^{\prime \prime}$ & 523 \\
K10 & $18^{\circ} 12^{\prime} 14.2848^{\prime \prime}$ & $9^{\circ} 7^{\prime} 51.33^{\prime \prime}$ & 525 \\
K11 & $18^{\circ} 10^{\prime} 18.8436^{\prime \prime}$ & $9^{\circ} 6^{\prime} 53.273^{\prime \prime}$ & 523 \\
K12 & $18^{\circ} 9^{\prime} 28.2708^{\prime \prime}$ & $9^{\circ} 6^{\prime} 15.016^{\prime \prime}$ & 522 \\
K13 & $18^{\circ} 9^{\prime} 11.3688^{\prime \prime}$ & $9^{\circ} 5^{\prime} 35.322^{\prime \prime}$ & 519 \\
K14 & $18^{\circ} 9^{\prime} 16.2864^{\prime \prime}$ & $9^{\circ} 4^{\prime} 4.89^{\prime \prime}$ & 513 \\
K15 & $18^{\circ} 9^{\prime} 42.7356^{\prime \prime}$ & $9^{\circ} 2^{\prime} 41.881^{\prime \prime}$ & 505 \\
\hline
\end{tabular}


Khamkeut is a district of Bolikhamxay province and located in the south of the province on latitude $18^{\circ} 21^{\prime} 8^{\prime \prime} \mathrm{N}$ and longitude $104^{\circ} 55^{\prime} 17^{\prime \prime} \mathrm{E}$. Khamkeut district is very full with natural forest, wildlife and rich of natural resource.The mountainous areas of Khamkeut district, generally stay much cooler with average temperatures of 11 degrees $\mathrm{C}$ during winter. The study area is around gold mine in Khamkeut district, close to the agricultural field and about $3 \mathrm{~km}$ from the city. The position of the investigation areas is listed in Table 1. The studied area is important from environmental, economical and natural preservation point of view.

\subsection{Preparation and processing of soil samples}

Soil samples were collected from 15 different locationsof the gold mining area in Khamkeut district, that are close to the populated areas and agriculture field. At every sampling site, the soil samples were collected from the surface layers $(5-30 \mathrm{~cm}$ depth) using a spade. Organic materials, piece of stones in the samples were removed. At the laboratory, the samples were dried in an oven at about $110^{\circ} \mathrm{C}$ for 6 hours. After drying, the samples were crushed and served with a mesh having holes each of diameter of $0.2 \mathrm{~mm}$.

Afterward, the homogenized samples were weighed and each sample was packed in a cylindrical plastic container of height $3 \mathrm{~cm}$ and $7.6 \mathrm{~cm}$ diameter. These were then stored for at least one month to ensure secular equilibrium between the parent radionuclides ${ }^{232} \mathrm{Th},{ }^{226} \mathrm{Ra}$ and their respective daughters.

\subsection{Measurement the gamma-ray of sample using $\mathrm{NaI}(\mathrm{Tl})$ scintillation detector}

In this work, we used the gamma - ray spectroscopy with a $2 \times 2$ inch $\mathrm{NaI}(\mathrm{Tl})$ crystal and photomultiplier tube (ORTEC model 276),890 V of the high voltage supply, 2.5 of amplification factor and multi - channel analyser with 4096 channels. The energy resolution (FWHM) and the absolute efficiency of detector were equal to $50 \mathrm{keV}$ and $14 \%$ at the $662 \mathrm{keV}$ of ${ }^{137} \mathrm{Cs} ; 70.5 \mathrm{keV}$ and $4.44 \%$ at $1332.5 \mathrm{keV}$ of ${ }^{60} \mathrm{Co}$. Spectra were collected and analyzed by Maestro-32 software. To calibrate energy of the gamma - ray spectrometry system, we have used the gamma peaks of ${ }^{137} \mathrm{Cs}$ $(661.65 \mathrm{keV}),{ }^{60} \mathrm{Co}(1173.22 \mathrm{keV}$ and $1332.50 \mathrm{keV}),{ }^{40} \mathrm{~K}(1460.80 \mathrm{keV}),{ }^{214} \mathrm{Bi}(1764.49 \mathrm{keV})$ and ${ }^{232} \mathrm{Th}(2614.53 \mathrm{keV})$. The soil samples and standard samples were kept one by one on the top detector and counted for period of $50.000 \mathrm{~s}$ to $100.000 \mathrm{~s}$.

\subsection{Determination activity of ${ }^{40} \mathrm{~K},{ }^{226} \mathrm{Ra}$ and ${ }^{232}$ Th according to the matrix method}

To determine the activity of ${ }^{40} \mathrm{~K},{ }^{226} \mathrm{Ra}$ and ${ }^{232} \mathrm{Th}$ according to the matrix method, the energy region of interest (ROI) for each isotope were selected (Fig.1).

To determine the $\mathrm{a}_{\mathrm{ik}}$ matrix in this work used standard samples RGK1, RGU1 and RGTh1 provided by the IAEA. The standard samples and the measurement samples weighted 180 grams, and were contained in a $7.6 \mathrm{~cm}$ diameter and $3 \mathrm{~cm}$ height plastic cylindrical box.The activitiesof the standard samplesare $2520 \pm 72,889.2 \pm 5.4$ and $585 \pm 16.2$ Bqfor ${ }^{40} \mathrm{~K},{ }^{226} \mathrm{Ra},{ }^{232} \mathrm{Th}$ respectively.

\subsection{Radium Equivalent Activity}

Radium equivalent activity is a widely used hazard index. It is calculated as follows [1]:

$\mathrm{Ra}_{\mathrm{eq}}=\mathrm{A}_{\mathrm{Ra}}+1.43 \mathrm{~A}_{\mathrm{Th}}+0.077 \mathrm{~A}_{\mathrm{K}}$

where $A_{R a}, A_{T h}$ and $A_{K}$ are the activities of ${ }^{226} \mathrm{Ra},{ }^{232} \mathrm{Th}$ and ${ }^{40} \mathrm{~K}$, respectively, in $\mathrm{Bq} / \mathrm{kg}$. It is assumed that $370 \mathrm{~Bq} / \mathrm{kg}$ of ${ }^{226} \mathrm{Ra}, 259 \mathrm{~Bq} / \mathrm{kg}$ of ${ }^{232} \mathrm{Th}$, and $4810 \mathrm{~Bq} / \mathrm{kg}$ of ${ }^{40} \mathrm{~K}$ produced the same 
gamma-ray dose rate. The maximum value of $\mathrm{Ra}_{\mathrm{eq}}$ must be $<370 \mathrm{~Bq} / \mathrm{kg}$ in order to keep the external dose $<1.5 \mathrm{mGy} / \mathrm{y}[1]$.

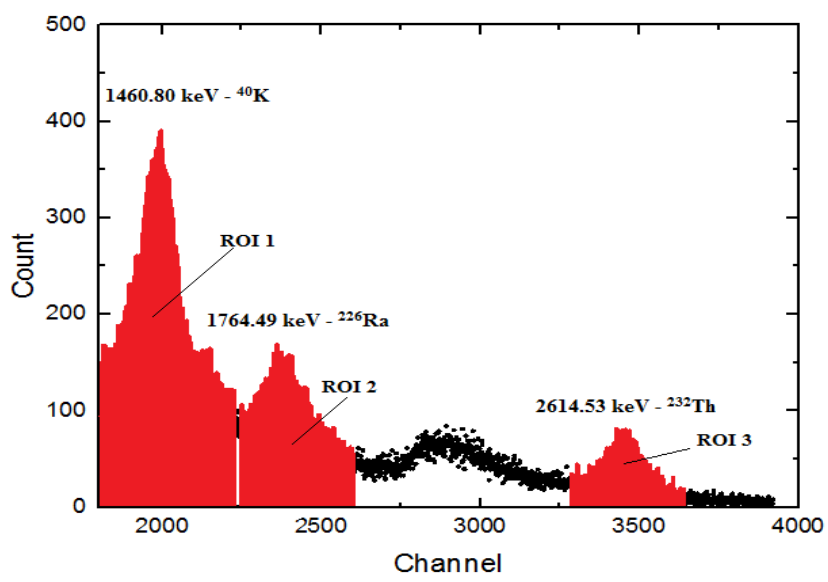

Fig. 1. The energy window characteristics for ${ }^{40} \mathrm{~K},{ }^{226} \mathrm{Ra}$ and ${ }^{232} \mathrm{Th}$.

\subsection{Air-Asorbed dose rate}

The absorbed dose rates in outdoor air (D) at about $1 \mathrm{~m}$ above the ground surface were calculated. The conversion factors used to compute absorbed gamma-ray dose rate in the air corresponds to 0.46 nGy h${ }^{-1}$ for ${ }^{226} \mathrm{Ra}, 0.62 \mathrm{Gyh}^{-1}$ for ${ }^{232} \mathrm{Th}$ and $0.042 \mathrm{nGyh}^{-1}$ for ${ }^{40} \mathrm{~K}$. Therefore, $\mathrm{D}_{\mathrm{R}}$ can be calculated according to $[1,3]$ :

$\mathrm{D}_{\mathrm{R}}\left(\mathrm{nGyh}^{-1}\right)=0.46 \mathrm{~A}_{\mathrm{Ra}}+0.62 \mathrm{~A}_{\mathrm{Th}}+0.042 \mathrm{~A}_{\mathrm{K}}$

\subsection{The External Hazard Index $\left(H_{e x}\right)$}

The external hazard index $\mathrm{H}_{\mathrm{ex}}$ is an assessment of the hazard of the natural gamma radiation. The main objective of hazard index to keep the value less than unity. $\mathrm{H}_{\mathrm{ex}}$ is defined by the following equation[2]:

$$
\mathrm{H}_{\mathrm{ex}}=\mathrm{A}_{\mathrm{Ra}} / 370+\mathrm{A}_{\mathrm{Th}} / 259+\mathrm{A}_{\mathrm{K}} / 4810
$$

\section{Results and discussion}

\subsection{Equation to calculate radioactivity concentration}

Based on k-th standard samples, the element $\mathrm{a}_{\mathrm{ik}}$ of matrix of instrument respone $\left\|a_{i k}\right\|$ is determined according to the following equation:

$$
a_{i k}=\frac{n_{i}}{A_{k}} \quad i=1,2,3 .
$$

From three standard samples(defined in table 3) matrix of $\left\|a_{i k}\right\|$ of are found be: 


$$
\left.a_{i k}=\mid \begin{array}{lll}
0.0001711 & 0.0005184 & 0.000322 \\
0 & 0.000439 & 0.0003332 \\
0 & 0.00000543 & 0.000325
\end{array}\right] \mid
$$

Radioactivities of ${ }^{40} \mathrm{~K},{ }^{226} \mathrm{Ra}$ and ${ }^{232} \mathrm{Th}$ were determined by the following equations:

$$
A_{i}=\frac{\Delta_{i}}{\Delta} \quad i=1,2,3 .
$$

$$
\text { where: } \Delta=\left|\begin{array}{lll}
0.0001711 & 0.0005184 & 0.000322 \\
0 & 0.000439 & 0.0003332 \\
0 & 0.00000543 & 0.000325
\end{array}\right|=2.41024 \times 10^{-11}
$$$$
\Delta_{1}=\left|\begin{array}{lll}
n_{1} & 0.0005184 & 0.000322 \\
n_{2} & 0.000439 & 0.0003332 \\
n_{3} & 0.0000043 & 0.000325
\end{array}\right|=1.4124224 \times 10^{-7} \times n_{1}-6.670954 \times 10^{-7} \times n_{2}+3.137288 \times 10^{-8} \times n_{3}
$$

$$
\begin{aligned}
\Delta_{2} & =\left|\begin{array}{lll}
0.0001711 & n_{1} & 0.000322 \\
0 & n_{2} & 0.0003332 \\
0 & n_{3} & 0.000325
\end{array}\right|=5.710 \times 10^{-8} \times n_{2}-5.69772 \times 10^{-8} \times n_{3} \\
\Delta_{3} & =\left|\begin{array}{lll}
0.0001711 & 0.0005184 & n_{1} \\
0 & 0.000439 & n_{2} \\
0 & 0.00000543 & n_{3}
\end{array}\right|=7.51129 \times 10^{-8} \times n_{3}-9.29073 \times 10^{-10} \times n_{2}
\end{aligned}
$$

Finally, the equation for calculating the radioactivity concentration of ${ }^{40} \mathrm{~K},{ }^{226} \mathrm{Ra}$ and ${ }^{232} \mathrm{Th}$ in soil samples defined as:

$$
\begin{aligned}
& A_{1}=5844.535 \times n_{1}-6917.674 \times n_{2}+1299.861 \times n_{3} \\
& A_{2}=2307.141 \times n_{2}-2365.417 \times n_{3} \\
& A_{3}=3116.410 \times n_{3}-38.511 \times n_{3}
\end{aligned}
$$

Where $\mathrm{n}_{\mathrm{i}}$ are countrate (cps) in the $\mathrm{i}-$ th ROI, ( $\mathrm{i}=1,2,3$ for ${ }^{40} \mathrm{~K},{ }^{226} \mathrm{Ra},{ }^{232} \mathrm{Th}$ ); $\mathrm{A}_{1}, \mathrm{~A}_{2}, \mathrm{~A}_{3}$ are radioactivity concentration of ${ }^{40} \mathrm{~K},{ }^{226} \mathrm{Ra}$ and ${ }^{232} \mathrm{Th}(\mathrm{Bq} / \mathrm{kg})$, respectively.

\subsection{Repetition and reliability of the NaI gamma ray spectrometer}

To test repetition and reliabilityof the gamma ray spectrometer with $\mathrm{NaI}(\mathrm{Tl})$ detector and the accuracy of equations (7a, 7b, 7c), we determined the activity of ${ }^{40} \mathrm{~K},{ }^{226} \mathrm{Ra}$ and ${ }^{232} \mathrm{Th}$ in standard sample TN at different times. Sample TN were prepared from samples RGK1, RGU1 and RGTh1 withmatrices of high purity: $\mathrm{SiO}_{2}, \mathrm{CaCO}, \mathrm{MgO}$, TiO (3, 2, 1, 0.5). Matrices do not contain radioactive isotopes. The radioactivity of ${ }^{40} \mathrm{~K},{ }^{226} \mathrm{Ra}$ and ${ }^{232} \mathrm{Th}$ in the sample TN is $987.2 \pm 6.0 \mathrm{~Bq} / \mathrm{kg}, 330.2 \pm 9.1$ $\mathrm{Bq} / \mathrm{kg}$, and $220.2 \pm 6.3 \mathrm{~Bq} / \mathrm{kg}$.

Obtained results at different times are given in Fig.2. The radioactivity values of ${ }^{40} \mathrm{~K},{ }^{226} \mathrm{Ra}$ and ${ }^{232} \mathrm{Th}$ obtained in each measurement deviation from the mean value shall not exceed one times the 
standard deviation. The our result is good agreement with an estimated value. In the Table 4 show results of radioactivity concentration of ${ }^{40} \mathrm{~K},{ }^{226} \mathrm{Ra},{ }^{232} \mathrm{Th}$ from 2 soil samples determined by $\mathrm{NaI}(\mathrm{Tl})$ gamma-ray spectroscopycombined matrix method (4) in this work (a) compared to results from Institute of Nuclear Science and Technology (INST).To compare, we used student's $t$ - distribution. Each sample soil was calculated $\mathrm{t}_{\mathrm{K}}, \mathrm{t}_{\mathrm{Ra}}, \mathrm{t}_{\mathrm{Th}}$ by the following formula:

$$
t_{k}=\frac{\left(A_{1 k}-A_{2 k}\right)}{\sqrt{\sigma_{1 k}{ }^{2}+\sigma_{2 k}{ }^{2}}} \quad k={ }^{40} K,{ }^{226} R a,{ }^{232} T h
$$

where $\mathrm{A}_{1 \mathrm{k}}, \sigma_{1 k}$ are radioactivity and estimator for population standard deviation in this work.

$\mathrm{A}_{2 \mathrm{k}}, \sigma_{2 k}$ are the radioactivity and the estimator for the population standard deviation from theINST.

$t_{k}$ are parameters to compare with two average value obtain from differentlabolatories.

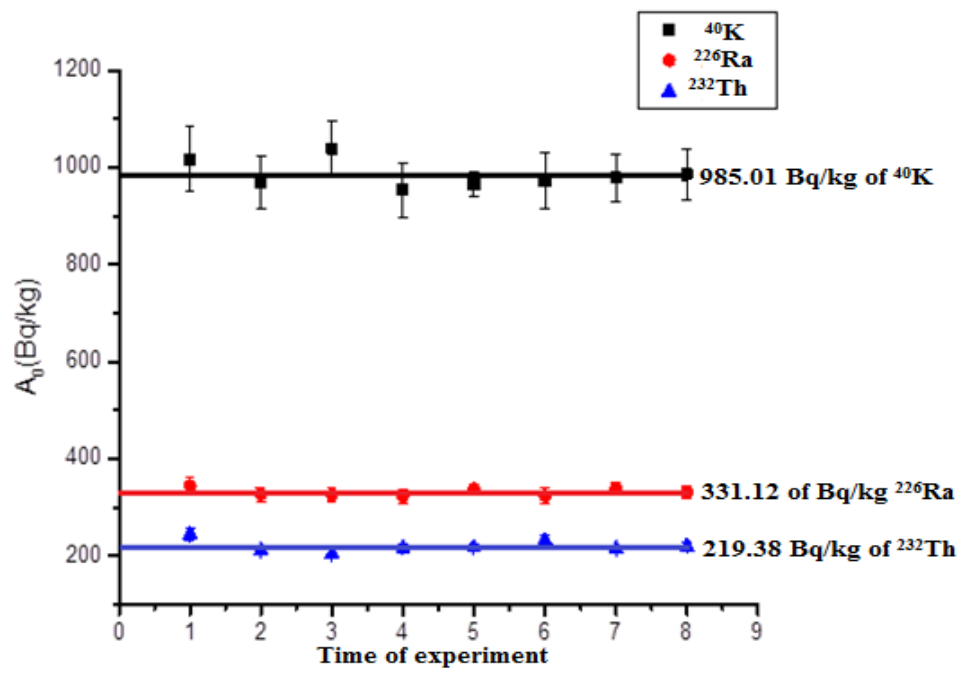

Fig. 2. Activity of ${ }^{40} \mathrm{~K},{ }^{226} \mathrm{Ra}$ and ${ }^{232} \mathrm{Th}$.in thesample TN determined at different times

Table 2. Comparison between our results (a) and others from INST (b)

\begin{tabular}{ccccccc}
\hline & ${ }^{40} \mathrm{~K}(\mathrm{~Bq} / \mathrm{kg})$ & ${ }^{226} \mathrm{Ra}(\mathrm{Bq} / \mathrm{kg})$ & ${ }^{232} \mathrm{Th}(\mathrm{Bq} / \mathrm{kg})$ & $\mathrm{t}_{\mathrm{K}}$ & $\mathrm{t}_{\mathrm{Ra}}$ & $\mathrm{t}_{\mathrm{Th}}$ \\
\hline $\mathrm{K} 2$ & $339.05 \pm 22.40$ & $39.91 \pm 2.8$ & $60.27 \pm 4.56^{(\mathrm{a})}$ & 0.97 & 1.24 & 0.65 \\
& $309.27 \pm 20.53$ & $44.92 \pm 2.90$ & $64.29 \pm 4.19^{(\mathrm{b})}$ & & & \\
$\mathrm{K} 14$ & $356.50 \pm 20.72$ & $39.66 \pm 2.99$ & $58.80 \pm 2.46^{(\mathrm{a})}$ & \multirow{2}{*}{1.70} & 0.71 & 0.89 \\
& $414.00 \pm 26.64$ & $42.54 \pm 2.75$ & $63.12 \pm 4.15^{(\mathrm{b})}$ & & & \\
\hline
\end{tabular}

All values of $t_{K}, t_{R a}, t_{T h}$ calculated are smaller than critical for $t_{0.05}=2.05$, which corresponds to a probability of $95 \%$. It shows that, our results are in good agreement with results obtained by INST. 


\subsection{The activity concentration of ${ }^{40} \mathrm{~K},{ }^{226} \mathrm{Ra}$ and ${ }^{232} \mathrm{Th}$ in the soil samples collected around gold mines} of Khamkurt district

The activity concentration of radionulides obtained from gamma-ray spectroscopy using $\mathrm{NaI}(\mathrm{Tl})$ scintillation detector for 15 soil samples collected from aroundthe gold mine in Khamkeut districtis presented in Table 3, with the uncertainty level of $\pm 2 \sigma$. The result of the activity concentration ${ }^{40} \mathrm{~K},{ }^{226} \mathrm{Ra}$ and ${ }^{232} \mathrm{Th}$ are shown in graphically in Fig. 3, Fig. 4 and Fig. 5, respectively.

The activity concentration of ${ }^{40} K$

The activity concentration of ${ }^{40} \mathrm{~K}$ ranges from $339.05 \pm 22.44$ to $873.08 \pm 36.26 \mathrm{~Bq} \cdot \mathrm{kg}^{-1}$ with an average value of $574.62 \pm 25.02 \mathrm{~Bq} \cdot \mathrm{kg}^{-1}$. The highest ${ }^{40} \mathrm{~K}$ activity concentration of $73.08 \pm 36.26 \mathrm{~Bq} \cdot \mathrm{kg}^{-1}$ was found in $\mathrm{K} 7$ in the gold mine and the lowest value of $339.05 \pm 22.44 \mathrm{~Bq} \cdot \mathrm{kg}^{-1}$ was found in K14aroundof thegold mining area in Khamkeut district.The average value is higher than in the world average of 400 Bq. $\mathrm{kg}^{-1}[1]$.

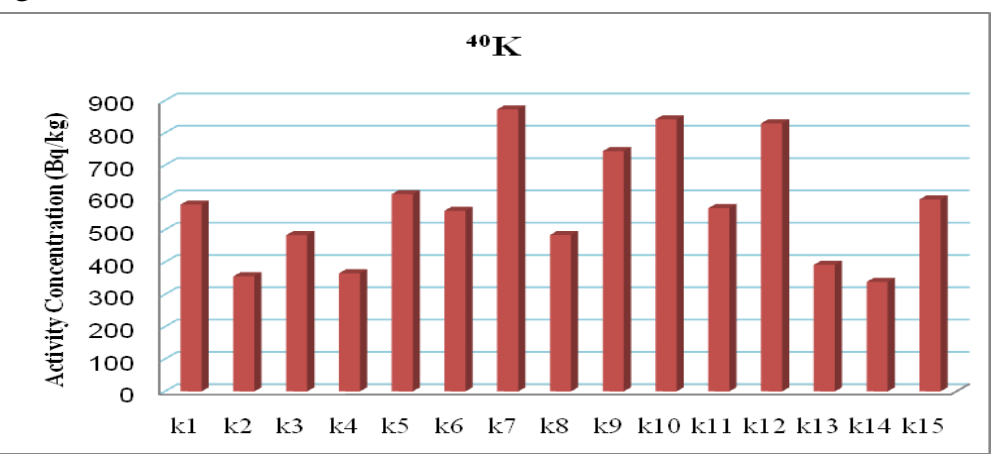

Fig. 3. Activity concentration of ${ }^{40} \mathrm{~K}$ in soil samples.

\section{Activity Concentration of ${ }^{226} \mathrm{Ra}$}

The concentration of ${ }^{226} \mathrm{Ra}$ ranges from $22.87 \pm 6.18 \mathrm{~Bq} \cdot \mathrm{kg}^{-1}$ to $69.87 \pm 8.78 \mathrm{~Bq} \cdot \mathrm{kg}^{-1}$. The lowest ${ }^{226} \mathrm{Ra}$ activity concentration of $22.87 \pm 6.18 \mathrm{~Bq} \cdot \mathrm{kg}^{-1}$ was found in $\mathrm{K} 7$ sample .The highest value for ${ }^{226} \mathrm{Ra}\left(69.87 \pm 8.78 \mathrm{~Bq} \cdot \mathrm{kg}^{-1}\right)$ was found in K9, (Fig.4). The average radioactivity for ${ }^{226} \mathrm{Ra}(46.58 \pm$ $\left.7.36 \mathrm{~Bq} \cdot \mathrm{kg}^{-1}\right)$ is higher than the world average value of $35 \mathrm{~Bq} \cdot \mathrm{kg}^{-1}[1]$.

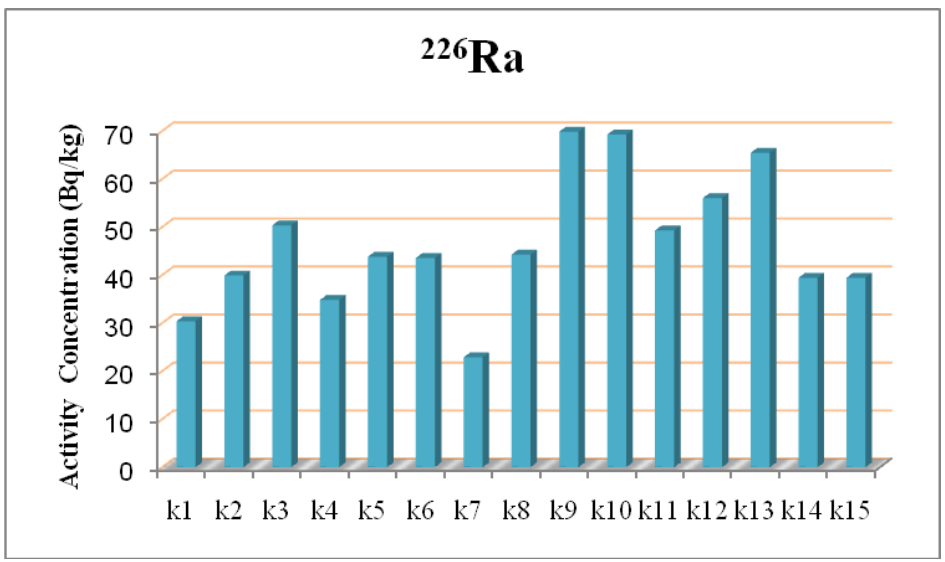

Fig. 4. Activity concentration of ${ }^{226} \mathrm{Ra}$ in soil samples. 
Activity concentration of ${ }^{232} \mathrm{Th}$

The ${ }^{232} \mathrm{Th}$ radioactivity concentration varies from $38.57 \pm 5.52$ to $89.32 \pm 4.08$ Bq. $\mathrm{kg}^{-1}$. The lowest ${ }^{232} \mathrm{Th}$ activity concentration of $38.57 \pm 5.52 \mathrm{~Bq} \cdot \mathrm{kg}^{-1}$ was found in $\mathrm{K} 7$. The highest ${ }^{232} \mathrm{Th}$ activity of $89.32 \pm 4.08 \mathrm{~Bq} \cdot \mathrm{kg}^{-1}$ was found in the K12, (Fig.5). The average radioactivity level of ${ }^{232} \mathrm{Th}$ of $71.19 \pm$ 7.3 Bq. $\mathrm{kg}^{-1}$ is higher than the world average of $30 \mathrm{~Bq} \cdot \mathrm{kg}^{-1}[1]$.

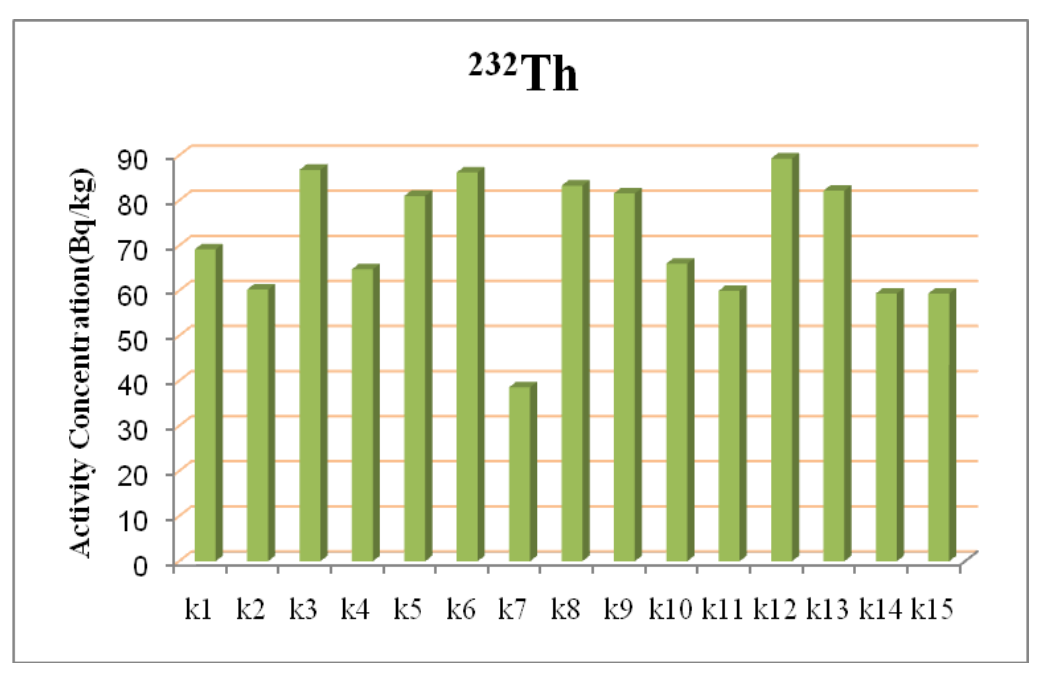

Fig. 5. Activityconcentration of ${ }^{232} \mathrm{Th}$ in soil samples.

\subsection{Radiological hazard assessment}

The result obtained of radium equivalent activity $\left(\mathrm{Ra}_{\mathrm{eq}}\right)$, the absorbed dose rate(D), outdoor annual effective dose rate $(\mathrm{E})$ and external hazard index $\left(\mathrm{H}_{\mathrm{ex}}\right)$ are shown in the table 3. We can be observed from Table 5, the calculated values of $\mathrm{Ra}_{\mathrm{eq}}$ for the same soil samples were found to vary from 145.25 $\pm 9.96 \mathrm{~Bq} \cdot \mathrm{kg}^{-1}$ to $247.67 \mathrm{~Bq}, \mathrm{~kg}^{-1}$. With the average values of $192.64 \pm 8.56 \mathrm{~Bq} \cdot \mathrm{kg}^{-1}$. These values are less than the limit value of $370 \mathrm{~Bq} \cdot \mathrm{kg}^{-1}$ [1]. The absorbed gamma dose (D) around the mines at Khamkeutdistrict varies from $67.98 \pm 3.32$ to $114.09 \pm 3.99 \mathrm{nGyh}^{-1}$ with an average value of $88.20 \pm 3.87 \mathrm{nGyh}^{-1}$. The maximum gamma dose rates were measured, the obtained result are higher than the world average of $59 \mathrm{nGyh}^{-1}[1]$.

The outdoor annual effective dose rates are in the range of 0.08 to $0.13 \mathrm{mSvyr}^{-1}$ with an average of $0.10 \mathrm{mSvyr}^{-1}$. The average values of (E) lower than the world average value of $0.460 \mathrm{mSvyr}^{-1}$ [1]. The estimated average values of external hazard index of $\mathrm{H}_{\mathrm{ex}}(0.52 \pm 0.02)$ in the study area were lower than unity as desirable.The values of hazard index confirm to population safety in the living and activity agriculture area.

\section{Conclusion}

In this study, gamma ray spectrometer with $\mathrm{NaI}(\mathrm{Tl})$ detector has been used to determine radioactivity concentration of ${ }^{40} \mathrm{~K},{ }^{226} \mathrm{Ra},{ }^{232} \mathrm{Th}$ in the soil samples collected in the gold mining areain Khamkeut district closely than with each other soil samples Bolikhamxay province, Laos [6]. The values of mean absorbed dose rate, annual effective dose and the radium equivalent activity were higher than the average values of Bolikhamxay Province, Laos and in the world. 
Whereas, the radium equivalent activity values are below $370 \mathrm{~Bq} / \mathrm{kg}$ the permissible limit and the external hazard index is less than unity. Therefore, the study areasare the zones of normal radiation level.

The main sources of the uncertainties for the present results were estimated due to statistical errors: $(2 \div 6 \%)$, errors of activities of standard samples $(0.8 \div 2.8 \%)$.

Table 3. Activity concentration of ${ }^{40} \mathrm{~K},{ }^{226} \mathrm{Ra}$ and ${ }^{232} \mathrm{Th}$ measured in soil samples together with radiological health.

\begin{tabular}{|c|c|c|c|c|c|c|c|}
\hline \multirow[t]{2}{*}{ Item } & \multicolumn{3}{|c|}{ Activity concentration in Bq. $\mathrm{kg}^{-1}$} & \multicolumn{4}{|c|}{ Radiological health parameter } \\
\hline & ${ }^{40} \mathrm{~K}$ & ${ }^{226} \mathrm{Ra}$ & ${ }^{232} \mathrm{Th}$ & $\mathrm{Ra}_{\mathrm{eq}}\left(\mathrm{Bq} \cdot \mathrm{kg}^{-1}\right)$ & $\mathrm{D}\left(\mathrm{nGy} \cdot \mathrm{h}^{-1}\right)$ & $\mathrm{E}\left(\mathrm{mSv} \cdot \mathrm{yr}^{-1}\right)$ & $\mathrm{H}_{\mathrm{ex}}(\mathrm{Bq} / \mathrm{kg})$ \\
\hline K1 & $578.54 \pm 16.20$ & $30.40 \pm 3.95$ & $69.18 \pm 3.30$ & $173.87 \pm 9.91$ & $79.67 \pm 4.48$ & $0.09 \pm 0.005$ & $0.74 \pm 0.02$ \\
\hline $\mathrm{K} 2$ & $356.37 \pm 10.72$ & $39.91 \pm 2.8$ & $60.27 \pm 2.28$ & $153.53 \pm 6.88$ & $69.46 \pm 3.10$ & $0.08 \pm 0.003$ & $0.41 \pm 0.01$ \\
\hline K3 & $483.58 \pm 11.67$ & $50.35 \pm 2.91$ & $86.81 \pm 2.48$ & $211.74 \pm 6.89$ & $95.52 \pm 3.12$ & $0.11 \pm 0.003$ & $0.57 \pm 0.02$ \\
\hline K4 & $365.46 \pm 10.70$ & $34.83 \pm 2.82$ & $64.76 \pm 2.32$ & $155.57 \pm 6.29$ & $70.18 \pm 2.85$ & $0.09 \pm 0.003$ & $0.42 \pm 0.02$ \\
\hline K5 & $610.60 \pm 11.78$ & $43.23 \pm 2.83$ & $81.02 \pm 2.44$ & $206.69 \pm 8.58$ & $94.32 \pm 3.83$ & $0.12 \pm 0.004$ & $0.55 \pm 0.02$ \\
\hline K6 & $559.16 \pm 11.90$ & $43.55 \pm 3.08$ & $86.22 \pm 2.50$ & $209.9 \pm 13.82$ & $95.17 \pm 6.25$ & $0.12 \pm 0.007$ & $0.56 \pm 0.04$ \\
\hline K7 & $873.08 \pm 18.23$ & $22.87 \pm 3.90$ & $38.57 \pm 3.26$ & $145.25 \pm 9.96$ & $70.12 \pm 4.52$ & $0.08 \pm 0.005$ & $0.39 \pm 0.03$ \\
\hline K8 & $484.17 \pm 13.90$ & $44.26 \pm 3.61$ & $83.29 \pm 3.02$ & $200.65 \pm 8.99$ & $90.61 \pm 4.06$ & $0.11 \pm 0.004$ & $0.54 \pm 0.02$ \\
\hline K9 & $743.74 \pm 12.51$ & $69.87 \pm 3.10$ & $81.57 \pm 2.50$ & $243.78 \pm 8.99$ & $112.24 \pm 4.7$ & $0.14 \pm 0.005$ & $0.65 \pm 0.02$ \\
\hline K10 & $842.25 \pm 13.38$ & $69.26 \pm 4.55$ & $66.00 \pm 2.64$ & $228.49 \pm 9.35$ & $106.72 \pm 4.2$ & $0.13 \pm 0.005$ & $0.62 \pm 0.03$ \\
\hline K11 & $567.17 \pm 11.09$ & $49.30 \pm 2.65$ & $59.98 \pm 2.27$ & $178.74 \pm 6.75$ & $82.42 \pm 3.05$ & $0.10 \pm 0.003$ & $0.48 \pm 0.01$ \\
\hline K12 & $836.25 \pm 12.56$ & $35.79 \pm 3.06$ & $88.14 \pm 2.60$ & $247.67 \pm 8.81$ & $114.09 \pm 3.9$ & $0.14 \pm 0.005$ & $0.67 \pm 0.02$ \\
\hline K13 & $392.02 \pm 11.66$ & $65.47 \pm 3.01$ & $82.19 \pm 2.53$ & $213.18 \pm 7.52$ & $95.91 \pm 3.39$ & $0.11 \pm 0.004$ & $0.57 \pm 0.02$ \\
\hline K14 & $339.05 \pm 11.28$ & $39.66 \pm 2.99$ & $56.80 \pm 2.46$ & $150.44 \pm 7.37$ & $67.98 \pm 3.33$ & $0.08 \pm 0.004$ & $0.41 \pm 0.01$ \\
\hline K15 & $594.04 \pm 11.77$ & $39.44 \pm 2.93$ & $59.37 \pm 2.40$ & $170.08 \pm 8.31$ & $78.61 \pm 3.76$ & $0.09 \pm 0.004$ & $0.45 \pm 0.02$ \\
\hline Averg & $574.62 \pm 25.02$ & $46.58 \pm 7.36$ & $71.19 \pm 5.42$ & $192.64 \pm 8.56$ & $88.20 \pm 3.87$ & $0.10 \pm 0.005$ & $0.52 \pm 0.02$ \\
\hline $\mathrm{a}^{*}[6]$ & $413.90 \pm 22.4$ & $43.80 \pm 10.6$ & $57.11 \pm 14.31$ & $158.75 \pm 16.10$ & $71.69 \pm 14.3$ & $0.09 \pm 0.01$ & $0.44 \pm 0.05$ \\
\hline $\mathrm{b}^{*}[1]$ & 400 & 35 & 30 & 370 & 59 & 0.48 & 1 \\
\hline
\end{tabular}

$a^{*}$ Bolikhamxay Province; $b^{*}$ UNSCEAR2000.

\section{Acknowledgements}

This research is funded by VNU University of Science under Project number TN.18.04.

\section{References}

[1] UNSCEAR United National Scientific Committee on the Effectsof Atomic Radiation Sources and Risks of Ionizing Radiation,Report to the General Assembly with Annexes, United Nations,New York, 2000.

[2] N.Q.Huy et al., Natural radioactivity and external does assessment of surcface soils in Vietnam. Radiation Protection Dosimetry), 151, 3,(2012) 522-531. 
[3] Alamgir Miah et al., Natural Radioactivity and Associated Dose Rates in soil Samples of Malnichera Tea Garden in Sylhet District of Bangladesh. Nuclear and particle Physics,2(6)(2012)147-152.

[4] Giorgia Cinelli et. al., Calibration with MCNP of NaI detector for the determination of natural radioactivity levels in the field. Journal of Environment Radioactivity 155-156 (2016) 31-37

[5] Gyuk P.M, Habila S.S, Dogara M.D, Kure N, DanielH.1, Handan T.E, Determination of Radioactivity level in soil samples at Chikun Environment of Kaduna Metropolis Using gamma ray spectrometry.Science World Journal, 12, 2 (2017) 52-55

[6] Somsavath Leuangtakoun, Bui Van Loat,Vu Thi Kim Duyen, Khong Nam Khang, Natural Radioactivity and External Dose Assessment of Surface Soil in Bolikhamxay Province,Laos. VNU Journal of Science: Mathematics of Physics,Vol.33,No.4(2017) 10-16 